\title{
Genetic variation in rate and extent of the in situ cell wall degradation of maize stalks at silage harvest time
}

\author{
Yves Barrière ${ }^{\mathrm{a}^{*}}$, Maria-Rosario Tovar-Gómez ${ }^{\mathrm{a}}$, Jean-Claude Émile ${ }^{\mathrm{a}}$, Daniel Sauvant ${ }^{\mathrm{b}}$ \\ ${ }^{\text {a }}$ Station d'amélioration des plantes fourragères, Inra, 86600 Lusignan, France \\ ${ }^{\mathrm{b}}$ INAPG, Laboratoire de nutrition et alimentation, 16, rue Claude Bernard, 75231 Paris cedex 05, France
}

(Received 30 August 1997; accepted 29 September 1998)

\begin{abstract}
Genetic variation in in situ degradability traits of the NDF part of maize stalks at silage harvest time has been studied, as part of the research for an ingestibility criterion in silage maize breeding, for 2 years with nine (including two brown-midrib-3 hybrids) and six hybrids, respectively. The extent of degraded NDF, expressed as a percentage of NDF in original samples, was significantly different between hybrids in each of the eight periods of incubation within cow rumens. After the modelling of degradation curves, the lag times and the contents in degradable fractions were also proved to be subjected to genetic variations in normal hybrids. The rate of degradation was nearly twice as much between extreme hybrids. None of the kinetic traits was related to the biochemical composition of the stalks, except a relation between the lignification degree and the extent of indegradable fraction. The rate of NDF degradation in stalks was free of lignin and cell wall carbohydrate contents. Further studies are now necessary in order to validate that traits of in situ degradability, such as the ratio $p_{r}=\left(p_{24}-p_{8}\right) /\left(100-p_{72}\right)$, could possibly be related to variations in the ingestibility of maize hybrids $\left(\mathrm{p}_{\mathrm{i}}\right.$ is the extent of degradation after $\mathrm{i}$ hours of incubation). (@ Inra/Elsevier, Paris.)
\end{abstract}

silage maize / in situ degradability / ingestibility / digestibility / bm3 hybrids / genetic variation

Résumé - Variabilité génétique des paramètres de dégradabilité in situ de tiges d'hybrides de maïs au stade de récolte ensilage. En vue de la recherche de critères de sélection de l'ingestibilité chez le maïs ensilage, une étude préliminaire de la variabilité génétique des caractéristiques de dégradabilité in situ de la fraction NDF a été conduite sur les tiges de respectivement 9 (dont 2 brown-midrib-3) et 6 hybrides de maïs, 2 années consécutives. Des effets génotypes significatifs ont été mis en évidence pour les quantités de NDF dégradées à chacun des huit temps d'incubation des échantillons dans le rumen. Après modélisation des courbes de dégradation, les proportions des fractions dégradables apparaissaient également génétiquement variables, avec des vitesses de dégradation presque doubles entre hybrides normaux extrêmes. Hormis une liaison entre fraction indégradable et degré de lignification, aucune de ces caractéristiques n'a pu être reliée clairement à des caractéristiques de composition biochimiques des tiges des hybrides. La vitesse de

Communicated by André Gallais (Gif-sur-Yvette, France)

* Correspondence and reprints

Telephone 33 (0)5 495560 32; fax number 33 (0)5 495560 44; e-mail: barriere@lusignan.inra.fr 
dégradation du NDF des tiges semblait en particulier indépendante des teneurs en lignines et en glucides pariétaux. Il convient maintenant de confirmer la variabilité des cinétiques de dégradation observée, et d'étudier dans quelle mesure certaines caractéristiques, dont l'index $\mathrm{p}_{\mathrm{r}}=\left(\mathrm{p}_{24}-\mathrm{p}_{8}\right) /\left(100-\mathrm{p}_{72}\right)$, pourraient être utilisés comme prédicteurs de l'ingestibilité (« $p_{i} »$ est la dégradation observée après i heures d'incubation). (@ Inra/Elsevier, Paris.)

maïs ensilage / dégradabilité in situ / ingestibilité / digestibilité / hybrides bm3 / variabilité génétique

\section{INTRODUCTION}

The main aim in silage maize breeding, for feeding value traits, is to increase the net energy supplied by forage in cattle diet. The variation in net energy intake of a maize cultivar is related to the variations in the digestibility of the stover and in the ear content, but also to the variation in its ingestibility and to the digestive interactions between the forage and the concentrates in the diet.

Research has clearly proved that a significant genetic variation in digestibility exists among normal maize hybrids regarding in vivo or in vitro dry matter, organic matter and/or cell wall digestibility. Reliable in vitro tests in breeding maize for digestibility traits are available to plant breeders, and are both easy and cheap to manage because of the use of near infrared reflectance spectroscopy (NIRS) (for a review, see Barrière et al. [3]). But the dry-matter intake of silage maize affects, as much as does digestibility, the supply of energy brought to cattle by a maize silage. However, at the present time, no prediction tool is available for estimating silage ingestibility. The silage maize voluntary intake by standard sheep is not related to the intake of dairy cattle, despite the fact that it has been observed for grasses $[6,9,11,28]$. The filling capacity of maize silage, and hence its ingestibility, could depend on: i) the rate of silage particle size reduction during animal rumination; and ii) the rate and extent of ruminal degradation of the cell wall. Very little is known, in maize forage, regarding variations existing in the rate of grinding and degradation, especially when related to a genotype effect at silage harvest time. Hunt et al. [16] demonstrated differences in ruminal fermentability of maize whole plants and stover affected by genotypes, but only one period of incubation $(24 \mathrm{~h})$ was studied. Klop and de Visser [21] gave data on the variation in organic matter and cell wall silage maize rates of degradation, but mostly related to year, location and maturity effects. Jung et al. [19] recently proved a great range of variations in NDF degradation kinetics of basal maize stalk internodes harvested at silking stage, and incubated in rumen fluid. The potential extent of NDF digestion ranged, in that experiment, from 48.4 to $71.1 \%$, when excluding brown midrib lines.

Before investigating further an ingestibility breeding criterion, the objective of the present work was to study the variations in in situ cell wall degradation kinetic traits in stalks of maize hybrids, of various genetic backgrounds and various agronomic and feeding values.

\section{MATERIALS AND METHODS}

\subsection{Plant material}

Table I gives a list of the hybrids studied in the in situ degradability experiments. Hybrids were early or medium early genotypes registered in France or in the Netherlands, or were experimental hybrids of Inra Lusignan or of the van der Have company. Hybrids were chosen as representative of various digestibility values, as already seen in prior experiments with sheep. Two brown-midrib-3 (bm3) isogenic hybrids were investigated as controls of high values in digestibility and ingestibility. Maize hybrids were grown in 1994 (experiment 1) and in 1995 (experiment 2) at the Inra forage plant breeding centre (Lusignan, central western France). Results were considered here only for the hybrids whose dry-matter content of the whole plant at harvest time ranged between 30.0 and $35.0 \%$ (nine in 1994 including two bm3 hybrids; six in 1995; Adonis was observed each year). Only plant stalks were studied because of their greater homogeneity in plant tissue and their importance in limiting digestibility of whole plant forage. Each year, the stalks, without leaves and leaf sheaths, were harvest- 
Table I. List of the hybrids used in the in situ degradability experiments (exp.: experimental).

\begin{tabular}{lccc}
\hline & FAO & Registered in & $\begin{array}{c}\text { used in } \\
\text { experiment }\end{array}$ \\
\hline Adonis & 280 & 1984, France & $1-2$ \\
Adonis bm3 & 290 & Inra-Coop Pau exp. & 1 \\
Dk265 & 260 & 1987, France & 1 \\
Ex213 & 270 & van der Have exp. & 2 \\
Ex223 & 270 & Inra exp. & 1 \\
Ex223 bm3 & 280 & Inra exp. & 1 \\
Ex232 & 290 & Inra exp. & 1 \\
Rh162 & 280 & 1990, France & 1 \\
Rh178 & 280 & 1991, France & 2 \\
Rh208 & 290 & 1992, France & 1 \\
Rh225 & 380 & 1992, France & 1 \\
Rh207 & 220 & 1993, France & 2 \\
Rh250 & 270 & 1994, France & 2 \\
Rh254 & 230 & 1994, the Netherlands & 2 \\
\hline
\end{tabular}

ed from the base up to the ear node. For practical reasons, all hybrid stalks were harvested within a day in experiment 1 , while, in experiment 2 , hybrid stalks were harvested according to the silking date. Stalks were roughly chopped, dried at $60{ }^{\circ} \mathrm{C}$, then ground with a 2 $\mathrm{mm}$ hammer mill screen for an in situ evaluation, and with a $1 \mathrm{~mm}$ screen for chemical analyses.

\subsection{Chemical composition}

Neutral and acid detergent fibres (NDF, ADF) and acid detergent lignin (ADL) were determined according to the Goering and Van Soest [12] method. As usual, the hemicellulose and cellulose contents were estimated as NDF - ADF and ADF - ADL, respectively. Soluble carbohydrate contents were obtained using the Lila [23] method. Each analysis was performed in duplicate.

\subsection{Studies of in situ degradability}

The in situ assessments of stalk degradation were carried out using four dry Holstein cows fitted with a permanent ruminal cannula. Cows were adapted to their diet during a 3 week period. The animals received a diet of alfalfa hay and concentrate $(70: 30 ; 1.3 \% \mathrm{BW}$ per day) at 0800 and 1600 hours, and had continuous access to water. The concentrate composition was as described by Michalet-Doreau et al. [26], and a blooming alfalfa hay was usually used as standard feed. The methodology of the used in situ degradation procedure was previously detailed by Tovar-Gómez et al. [32].

Six grams of each hybrid sample were placed in nylon bags (Ankom Company, Fairport, New York, USA, internal size $20 \times 10 \mathrm{~cm}$, pore size $52 \pm 7 \mu \mathrm{m}$, yielding a sample mass/bag area ratio of $15 \mathrm{mg} / \mathrm{cm}^{2}$ ). Individual bags were placed in the ventral sac of the rumen just before the morning feed, and then removed after $2,4,8$, $12,24,48,72$ or $96 \mathrm{~h}$ of incubation. Following incubation, the bags were frozen and thawed to remove bacteria from residues [20], then machine-washed three times in cold water (for 5 min each time), and then dried at $60{ }^{\circ} \mathrm{C}$ for $72 \mathrm{~h}$. There were eight individual values for each estimated point per hybrid and per time (four cows, two replicates per cow), but the two replicates were melted before the NDF analysis.

The loss of undegraded particles through the pores of the bags, which could result in an overestimation of the degradability, was assessed. Control bags were placed, for each hybrid in a carbonate-phosphate buffer solution of $\mathrm{pH} 8$, and shook for $2 \mathrm{~h}$ in a $40^{\circ} \mathrm{C}$ waterbath. Particles which escaped were recovered from the solution by filtration. All measurements were carried out in triplicate, and some aberrant values had to be discarded. Average losses were 8.9 and $8.0 \%$ in experiments 1 and 2 , respectively. NDF disappearances were then corrected according to Lopez et al. [24], assuming that the escaped particles were only made of NDF, all the other constituents of a maize stalk being mostly soluble, or negligible.

\subsection{Data analysis}

The hybrids NDF degradation kinetics were fitted to an exponential model, according to Orskov and McDonald [29], with a lag time $\left(t_{0}\right)$ according to Danhoa [10], without any soluble fraction in NDF [30] such as

$$
\begin{gathered}
p=0 \text { for } t \leq t_{o}, \\
\text { and } p=b\left(1-e^{-c(t-t o)}\right) \text { for } t>t_{o}
\end{gathered}
$$

where $\mathrm{p}$ is the degradation $(\%), \mathrm{b}$ is the potentially degradable fraction $(\%), \mathrm{c}$ is the fractional degradation rate $\left(h^{-1}\right)$ of $b, t$ is the time of incubation $(h)$ and $t_{0}$ is the lag time (h). Parameter values were obtained through a non-linear regression procedure, performed by the 'nls2' 
procedure of Splus software [33]. Cell wall degradation after $8\left(\mathrm{p}_{8}\right)$ and $24 \mathrm{~h}\left(\mathrm{p}_{24}\right)$ as a percentage of cell wall degradation after $72 \mathrm{~h}\left(\mathrm{p}_{72}\right)$ was also investigated as $\mathrm{p}_{8 / 72}$ and $\mathrm{p}_{24 / 72}$, as proposed by Wilman et al. [34] for the $\mathrm{p}_{24 / 72}$ ratio. Similarly, the ratio $\mathrm{p}_{\mathrm{r}}=\left(\mathrm{p}_{24}-\mathrm{p}_{8}\right) /\left(100-\mathrm{p}_{72}\right)$, which summarises the estimates of rate and extent of degradation, was investigated as an index of the potential efficiency of the genotype.

Genotypic variation of in situ cell wall degradation traits was then investigated through an usual analysis of variance model, with a block design, including cow and hybrid effects, but excluding bm 3 hybrids (Modli, InraBiométrie software). As the studied hybrids were not a random sample, genotypic variances were estimated as $\Phi_{\mathrm{G}}=\left(\mathrm{CM}_{\mathrm{G}}-\mathrm{CM}_{\mathrm{E}}\right) / \mathrm{n}_{\mathrm{G}}$ where $\mathrm{CM}_{\mathrm{G}}$ and $\mathrm{CM}_{\mathrm{E}}$ are the genotypic and residual meansquares and $n_{G}$ the number of observations of each genotype (see [8]).

\section{RESULTS}

\subsection{Chemical composition}

Organic matter contents of stalks were similar between hybrids, and were 93.8 and $94.3 \%$ in experiments 1 and 2 , respectively. The range of variations in the chemical composition of maize hybrid stalks was about the same in all chemical traits of experiments 1 and 2 (table $I I$ ). However, lower hemicellulose and higher cellulose or ADF contents were observed in experiment 2 , with confused effects between environmental and genotypic effects. The most lignified hybrid, Rh162, had a ADL/NDF content about 1/2 higher than the lowest

Table II. Contents in biochemical components (\% of dry-matter) of the maize hybrid stalks used in degradation experiments. (Normal hybrids are ranked according to their decreasing lignification degree.)

\begin{tabular}{|c|c|c|c|c|c|c|c|}
\hline Hybrid & $\begin{array}{c}\text { Soluble } \\
\text { carbohydrate }\end{array}$ & NDF & $\mathrm{ADF}$ & $\mathrm{ADL}$ & $\mathrm{ADL} / \mathrm{NDF}$ & $\begin{array}{l}\text { Hemi- } \\
\text { cellulose }\end{array}$ & Cellulose \\
\hline \multicolumn{8}{|c|}{ Experiment 1 (1994) } \\
\hline Rh162 & 15.8 & 64.5 & 40.2 & 6.8 & 10.5 & 24.3 & 33.4 \\
\hline Rh225 & 7.7 & 73.4 & 49.6 & 7.3 & 10.0 & 23.8 & 42.3 \\
\hline Rh208 & 17.9 & 62.6 & 37.9 & 6.0 & 9.6 & 24.7 & 31.9 \\
\hline Adonis & 21.9 & 54.6 & 35.1 & 4.8 & 9.6 & 19.5 & 30.3 \\
\hline Adonis bm 3 & 22.2 & 53.4 & 29.3 & 3.1 & 5.8 & 24.1 & 26.2 \\
\hline Ex232 & 26.0 & 53.0 & 33.0 & 4.8 & 9.1 & 20.0 & 28.2 \\
\hline Ex223 & 17.4 & 61.2 & 34.2 & 4.3 & 7.0 & 27.0 & 29.9 \\
\hline Ex223 bm3 & 29.1 & 44.2 & 22.6 & 1.2 & 2.7 & 21.6 & 21.4 \\
\hline Dk265 & 25.4 & 51.3 & 30.0 & 3.6 & 7.0 & 21.3 & 26.4 \\
\hline Mean n & 18.9 & 60.0 & 37.1 & 5.4 & 8.9 & 22.9 & 31.8 \\
\hline Mean n+bm3 & 20.4 & 57.6 & 34.7 & 4.6 & 7.8 & 22.9 & 30.0 \\
\hline \multicolumn{8}{|c|}{ Experiment 2 (1995) } \\
\hline Adonis & 18.3 & 61.7 & 42.8 & 6.0 & 9.7 & 18.9 & 36.8 \\
\hline Ex213 & 11.6 & 65.7 & 46.1 & 6.3 & 9.6 & 19.6 & 39.8 \\
\hline Rh207 & 25.2 & 56.7 & 39.2 & 5.3 & 9.3 & 17.5 & 33.9 \\
\hline Rh 178 & 15.1 & 68.4 & 46.8 & 6.1 & 9.0 & 21.6 & 40.6 \\
\hline Rh250 & 19.7 & 56.7 & 35.3 & 4.6 & 8.1 & 21.4 & 30.7 \\
\hline $\mathrm{Rh} 254$ & 25.1 & 52.4 & 34.9 & 4.0 & 7.6 & 17.5 & 30.9 \\
\hline Mean & 19.2 & 60.3 & 40.8 & 5.4 & 8.9 & 19.4 & 35.4 \\
\hline
\end{tabular}


normal ones, Ex223 or Dk265. Bm3 hybrids were mainly characterised by their low lignin contents.

\subsection{In situ NDF degradation kinetics}

Observed genotypic variations for degraded NDF contents in normal hybrids were significant at each sampling, except the $12 \mathrm{~h}$ measurement in experiment 2. Variations between hybrids, estimated as $\Phi_{\mathrm{G}}$ values, were variable according to the duration of incubation in the rumen, with lower variations after 2, 4 and $12 \mathrm{~h}$ of incubation (table III). Residual mean squares were distinctly higher at 8 , 12 and $24 \mathrm{~h}$, intermediate durations of incubation, probably pointing out a lower environmental effect at the beginning when no degradation occurred, and, at the end, when genotypic effects were more substantial. Whatever the year, the more discriminant duration of incubation was the $8 \mathrm{~h}$ duration in the early stages, and the $72 \mathrm{~h}$ duration for the latter stages.

Kinetics of NDF degradation are illustrated in figure 1 , for variation between normal hybrids and for comparisons between normal and bm 3 hybrids. There was a very good relevance of the model used $\left(\mathrm{r}^{2}\right.$ between observed and adjusted values higher than 0.94). Parameters of stalk NDF kinetics of degradation in normal hybrids exhibited highly significant genotypic differences in all investigated traits (table $I V$ ). The range of genotypic variations in degradable parts and rate of degradation were higher in experiment 1 than in experiment 2, and probably more related to the investigated germplasm, than to the environmental effects. Average rates of degradation were slightly lower than those given by Mertens [25] for normal maize stalks and stover $\left(10^{2} \mathrm{c}=4.4\right.$ and 5.0). Lag times of Mertens, for stalks and stover, surrounded the average values obtained here for stalks. Klop and de Visser [21], in the Netherlands, have observed a lower average degradation rate $\left(10^{2} \mathrm{c}=1.7\right)$, and higher $b$ fractions $(b=67.4)$, but the investigated germplasm and the regression models used were not the same. Hybrids having similar degradable $b$ fractions and similar lag times, such as Dk265 and
Table III. Content in degraded NDF, as a percentage of NDF content in original stalk samples, after different periods of in situ incubation, genetic variations $\Phi_{\mathrm{G}}$ and residual errors $\sigma^{2}$, excluding bm3 hybrids. All genotypic $F$ values for degraded NDF contents were significant at $P<0.01$, except after $12 \mathrm{~h}$ of incubation in experiment 2.

\begin{tabular}{lcccccc}
\hline & \multicolumn{3}{c}{ Experiment 1} & \multicolumn{3}{c}{ Experiment 2 } \\
Time & Mean ${ }_{\mathrm{G}}$ & $\Phi_{\mathrm{G}}$ & $\sigma_{\mathrm{c}}^{2}$ & Mean ${ }_{\mathrm{G}}$ & $\Phi_{\mathrm{G}}$ & $\sigma_{\mathrm{c}}^{2}$ \\
\hline $2 \mathrm{~h}$ & 1.3 & 0.2 & 0.08 & 1.3 & 0.1 & 0.09 \\
$4 \mathrm{~h}$ & 3.7 & 3.5 & 0.01 & 2.3 & 1.2 & 0.01 \\
$8 \mathrm{~h}$ & 8.1 & 14.2 & 1.06 & 7.1 & 5.0 & 1.04 \\
$12 \mathrm{~h}$ & 13.0 & 9.8 & 1.37 & 11.4 & 0.4 & 1.92 \\
$24 \mathrm{~h}$ & 27.5 & 15.6 & 1.23 & 24.3 & 11.0 & 1.44 \\
$48 \mathrm{~h}$ & 42.8 & 12.2 & 0.18 & 42.8 & 17.9 & 0.24 \\
$72 \mathrm{~h}$ & 48.4 & 18.0 & 0.01 & 49.5 & 15.5 & 0.01 \\
$96 \mathrm{~h}$ & 52.6 & 15.5 & 0.01 & 55.4 & 14.9 & 0.01 \\
\hline
\end{tabular}

Ex223, could have significantly different degradation rates. Hybrids with poor degradable fractions could have a high degradation rate, such as $\mathrm{Rh} 208$, or a low degradation rate such as $\mathrm{Rh} 162 . \mathrm{Bm} 3$ hybrids appeared different from normal hybrids mainly through their very higher $b$ values. When comparing the two experiments, Adonis had similar $\mathrm{p}_{\mathrm{r}}$ values in the two experiments, and it was the same for Rh162 and Rh178, genetically related hybrids.

No clear relationship could be shown between the chemical composition of stalk samples and their in situ degradation kinetics traits (when excluding bm 3 hybrids). In most cases, correlations were not constant throughout the two experiments, but the genetic variation for these traits was important only in experiment 1 . In this experiment 1 , the $b$ fraction was mostly related to the lignification degree $(r=$ -0.85 ). The degradation rate was mainly free of hemicellulose and cellulose contents, and it was also free of the lignification degree. The $\mathrm{p}_{24 / 72}$ ratio was related to the rate of degradation, but it only partly explained this trait $\left(r^{2}=0.58\right)$, despite the results of Wilman et al. [34] with forage grasses. The relationship was about similar between the degradation rate and the $\mathrm{p}_{08 / 72}$ ratio $\left(\mathrm{r}^{2}=0.66\right)$, but a slightly higher value was observed directly 

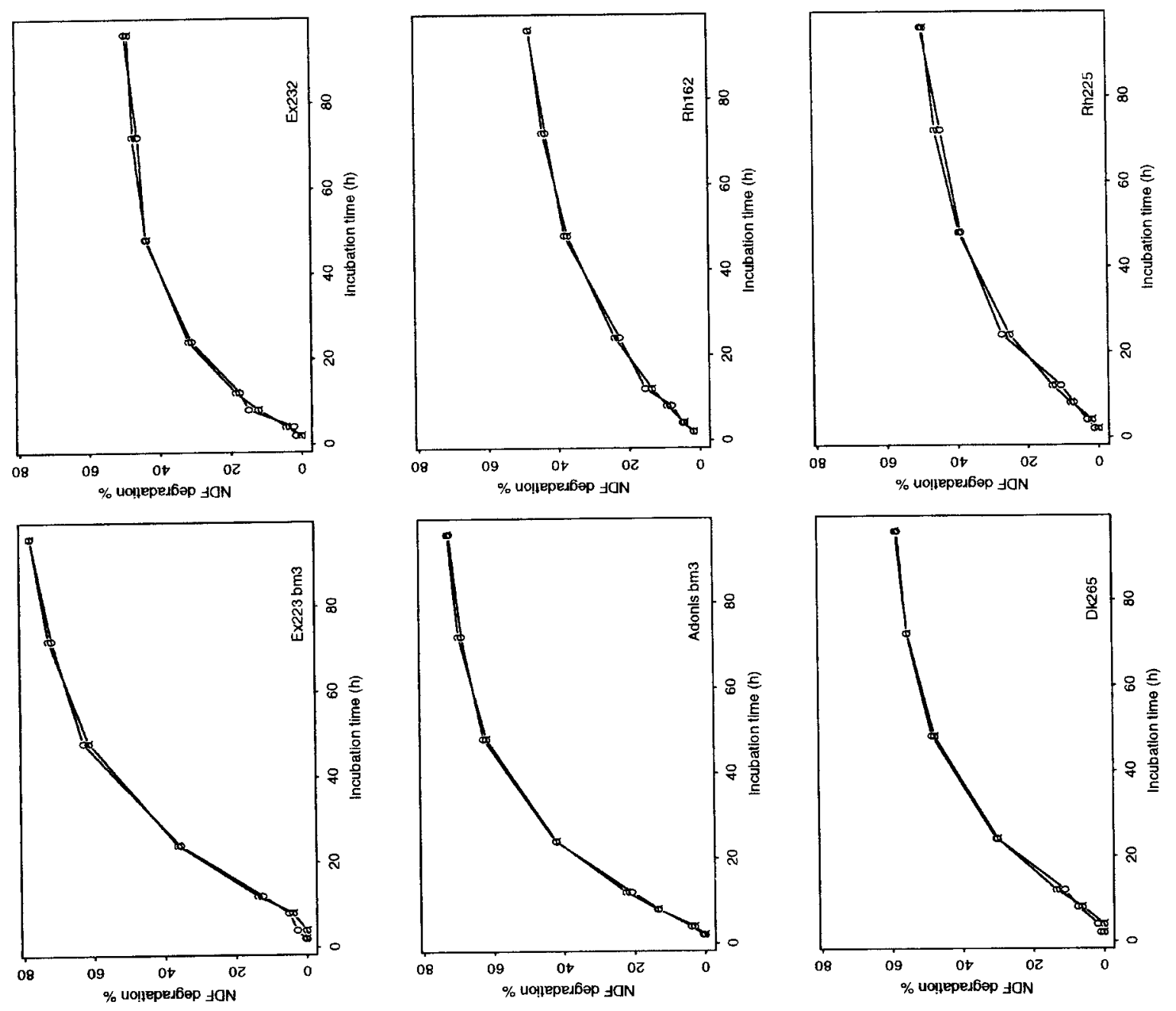

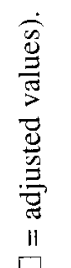
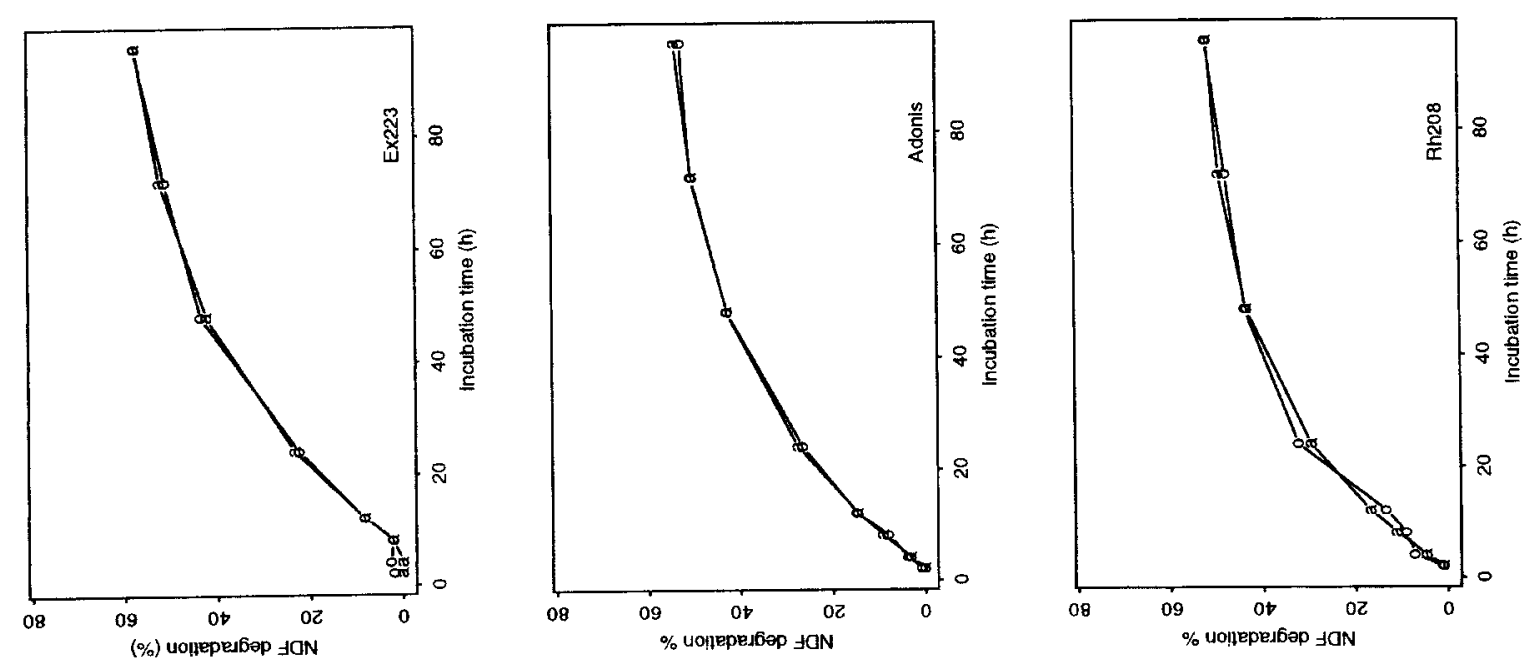

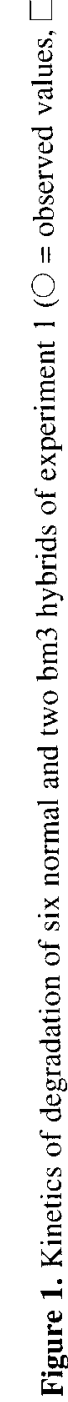


between the rate of degradation and the extent of degraded NDF after $8 \mathrm{~h}\left(\mathrm{r}^{2}=0.74\right)$. In the same way, the $b$ fraction was well correlated with the extent of degradation after 72 or $96 \mathrm{~h}\left(\mathrm{r}^{2}=0.68\right.$ and 0.88 ). The $\mathrm{p}_{\mathrm{r}}$ index ratio was neither correlated with

Table IV. Genotypic mean in NDF in situ degradation traits of hybrids maize stalks, confidence limit (5\% level), genotypic variation $\Phi_{\mathrm{G}}$ and $\mathrm{F}$ values.

Experiment 1

\begin{tabular}{lcccccc}
\hline Hybrid & $\mathrm{b}$ & $10^{2} \mathrm{c}$ & $\mathrm{t}_{\mathrm{o}}$ & $\mathrm{p}_{8 / 72}$ & $\mathrm{p}_{24 / 72}$ & $\mathrm{p}_{\mathrm{r}}$ \\
\hline Rh162 & 52.1 & 2.7 & 0.7 & 18.3 & 52.2 & 26.0 \\
Rh225 & 52.2 & 3.1 & 2.8 & 15.8 & 61.3 & 36.4 \\
Rh208 & 53.6 & 3.6 & 1.5 & 18.7 & 67.6 & 44.9 \\
Adonis & 57.4 & 3.0 & 2.2 & 15.7 & 52.4 & 37.6 \\
Ex232 & 49.3 & 4.7 & 2.1 & 32.6 & 67.4 & 29.8 \\
Ex223 & 63.5 & 2.6 & 6.8 & 4.1 & 43.6 & 41.4 \\
Dk265 & 60.9 & 3.6 & 5.0 & 13.4 & 54.7 & 51.5 \\
& & & & & & \\
Mean ${ }_{\mathrm{G}}$ & 55.6 & 3.3 & 3.0 & 16.9 & 57.0 & 38.2 \\
C limit & 1.0 & 0.3 & 0.4 & 2.0 & 2.3 & 0.6 \\
$\Phi_{\mathrm{G}}$ & 26.8 & 0.5 & 4.6 & 71.0 & 76.9 & 75.8 \\
F value & 113.2 & 25.0 & 131.7 & 78.7 & 63.8 & 798.2 \\
& & & & & & \\
Adonis bm3 & 74.4 & 4.0 & 3.0 & 19.2 & 61.5 & 93.5 \\
Ex223 bm3 $_{\text {Mean }} \mathrm{n}+\mathrm{bm} 3$ & 81.8 & 3.3 & 6.6 & 6.9 & 49.5 & 108.2 \\
C $_{\mathrm{G}}$ & 60.6 & 3.4 & 3.4 & 16.1 & 56.7 & 52.2 \\
\hline
\end{tabular}

Experiment 2

\begin{tabular}{lcccccc}
\hline Hybrid & $\mathrm{b}$ & $10^{2} \mathrm{c}$ & $\mathrm{t}_{\mathrm{o}}$ & $\mathrm{p}_{08 / 72}$ & $\mathrm{p}_{24 / 72}$ & $\mathrm{p}_{\mathrm{r}}$ \\
\hline Adonis & 61.8 & 2.3 & 3.2 & 12.8 & 49.8 & 35.0 \\
Ex213 & 64.3 & 2.3 & 1.6 & 19.5 & 53.1 & 32.6 \\
Rh207 & 66.2 & 2.7 & 2.8 & 18.2 & 51.1 & 41.3 \\
Rh178 & 58.7 & 2.0 & 2.0 & 11.2 & 44.1 & 26.2 \\
Rh250 & 58.8 & 2.7 & 4.8 & 9.8 & 44.7 & 31.5 \\
Rh254 & 61.0 & 2.9 & 4.4 & 13.8 & 50.4 & 39.9 \\
& & & & & & \\
Mean $_{\mathrm{G}}$ & 61.8 & 2.5 & 3.1 & 14.2 & 48.9 & 34.4 \\
C limit $_{\Phi_{\mathrm{G}}}$ & 2.5 & 0.3 & 0.1 & 2.2 & 2.6 & 0.2 \\
F value & 8.2 & 0.1 & 1.5 & 13.8 & 11.7 & 31.6 \\
& 13.7 & 16.3 & 15.6 & 14.1 & 8.9 & 980.1 \\
\hline
\end{tabular}

$b$ is degradable fraction, $c$ is fractional degradation rate, $t_{0}$ is lag time, $\mathrm{p}_{08 / 72}$ and $\mathrm{p}_{24 / 72}$ are the ratio between degraded parts at 8 or $24 \mathrm{~h}$ and $72 \mathrm{~h}$, and $\mathrm{p}_{\mathrm{r}}=\left(\mathrm{p}_{24}-\mathrm{p}_{8}\right) /\left(100-\mathrm{p}_{72}\right)$. All variance analyses were computed excluding bm 3 hybrids, and $F$ values were significant at $P<0.01$. Hybrids are ranked according to their decreasing lignification degree. the degradation rate $\left(r^{2}=0.00\right)$ nor with the $b$ fraction $\left(r^{2}=0.44\right)$.

Previous experiments in dairy cattle feeding [2, 5] indicated that the hybrid $\mathrm{Rh} 162$ had a poor digestibility and efficiency for cattle feeding, Dk265 had good digestibility, ingestibility and efficiency, and Adonis and Rh208 were intermediate. Rh162 also had the poorest values in all the degradation kinetic traits investigated. Dk265 had good values either in degradation rate and $b$ fraction. Adonis or $\mathrm{Rh} 208$ were intermediate according to the studied traits, closer to one or to the other of these base hybrids. The $\mathrm{p}_{\mathrm{r}}$ index appeared here as a criterion well related to the hybrid efficiency in cattle, with a double value in $\mathrm{Dk} 265$ compared to Rh162, and intermediate values in Adonis and Rh208. None of the other normal hybrids investigated, whatever the experiment, had a $\mathrm{p}_{\mathrm{r}}$ index as high as Dk265. Only bm3 hybrids, whose good digestibility and ingestibility were proved in dairy cattle [15], had a $\mathrm{p}_{\mathrm{r}}$ index higher than Dk265.

\section{DISCUSSION AND CONCLUSIONS}

Variations in silage ingestibility in dairy cattle, related to the maize hybrid effect, have been proved. They were assumed [27] to be related to genetic differences in friability, which is related to an easy mastication and to the duration of rumination. Differences in in situ degradability characteristics of the cell wall due to the hybrid effect were proved here in each of these two experiments. The variations in dry-matter intake of 54 temperate and tropical roughages by goats and sheep were indeed predicted [5] from stepwise multiple regressions of the kinetic parameters based on isolated NDF incubation in a gas-test system $\left(\mathrm{r}^{2}=0.81\right)$. The results detailed here are obviously not sufficient enough in establishing definite conclusions. Further, in situ and dairy cow coupled experiments might validate the hypothesis that ingestibility could be related to some traits observed or computed from the kinetics of degradation. However, a measurement in the extent of NDF degradation after 8,24 and $72 \mathrm{~h}$ provided about as much information as would have a 
full study. The $\mathrm{p}_{\mathrm{r}}$ index, computed with these three values, gave a ranking of hybrids similar to the one known from previous experiments with cattle, and was more relevant here than traits computed from a complete modelling of kinetics of degradation curves. Moreover, an investigation into eight sampling periods of degradation is not possible for a great number of hybrids and locations, unlike in maize breeding. Costs will also be reduced, and breeders efficiency enhanced, if NIRS calibration of these degradations in the animal's rumen could be developed. Herrero et al. [14], studying Pennisetum, suggested that the calibration of gas volumes was a more promising alternative than to fit specific parameters of kinetics fermentation models by NIRS. Jung et al. [19] also had good NIRS prediction of the extent of NDF degradation, with $r^{2}$ values close to 0.90 . These works proved that good calibrations were possible.

The observed genetic variation in normal hybrids did not relate for the greater part to the variations in structural carbohydrate contents in the maize genotype stalks, except for a relationship between the NDF indegradable part and the lignification degree. Degradability of the maize cell wall is also related to the biochemical composition of lignin, to the relationship between lignin and arabinoxylans, and to the spatial organisation between lignins and structural carbohydrates, rather than to the amount in each constituent $[1,4,13,17,18,22]$. Travis et al. [31] also proved that anatomical features, having an effect distinct from that due to an overall chemical composition, were involved in wheat and barley internode NDF digestibility. Genetic variations in arrangements of lignified areas in maize stalks should also provide informations on a comprehensive approach to silage maize ingestibility.

Acknowledgements: M.R. Tovar-Gómez, who conducted these experiments, was supported at Inra Lusignan by a doctoral grant from the 'Programme Franco-Mexicain de Coopération Scientifique et Technique' (CONACYT-SFERE). The authors are grateful to all contributors of these experiments for their technical assistance, especially R. Chargelègue, G. Goudeau, R. Traineau, S. Allerit, M. Bucher and V. Ménanteau. Many thanks to $\mathrm{C}$. Demarquilly (Inra, Nutrition des herbivores, Theix) for his helpful advice, criticisms and discussions. Thanks to G. Allard (Université Laval, Québec) and $O$. Argillier for their invaluable criticisms, and thanks to Y. Hébert and S. Huet (Inra Biométrie, Jouy en Josas) for their help in the non linear regression computing. Thanks to A. de Pourtalès for the English proof-reading.

\section{REFERENCES}

[1] Argillier O., Barrière Y., Lila M., Jeanneteau F., Gélinet K., Ménenteau F., Genotypic variation in phenolic components of cell walls in relation to the digestibility of maize stalks, Agronomie 16 (1996) 123-130.

[2] Barrière Y., Emile J.C., Traineau R., Hébert Y., Genetic variation in the feeding efficiency of maize genotypes evaluated from experiments with dairy cows, Plant Breeding 114 (1995) 144-148

[3] Barrière Y., Argillier O., Michalet-Doreau B., Hébert Y., Guingo E., Giauffret C., Emile J.C., Relevant traits, genetic variation and breeding strategies in early silage maize, Agronomie 17 (1997) 395-411.

[4] Besle J.M., Cornu A., Jouany J.P., Roles of structural phenylpropanoids in forage cell wall digestion, $\mathrm{J}$. Sci. Food Agric. 64 (1994) 171-190.

[5] Blümmel M., Makkar H.P.S., Chisanga G., Mtimuni J., Becker K., The prediction of dry matter intake of temperate and tropical roughages from in vitro digestibility/gas-production data, and the dry matter intake and in vitro digestibility of African roughages in relation to ruminant liveweight gain, Anim. Feed Sci. Technol. 69 (1997) 131-141.

[6] Chenost M., Martin-Rosset W., Comparaison entre espèces (mouton, cheval, bovin) de la digestibilité et des quantités ingérées des fourrages verts, Ann. Zootech. 34 (1985) 291-312.

[7] Ciba-semences., Valorisation laitière d'une variété de maïs en ensilage, Synthesis of an experimentation conducted by the EDE of Vendée during 1988-89-90, $1990,13 \mathrm{p}$.

[8] Dagnelie P., Théorie et méthodes statistiques, Les presses agronomiques de Gembloux, ASBL, 1973.

[9] Demarquilly C., Weiss P., Liaisons entre les quantités de matière sèche de fourrage vert ingérées par les moutons et celles ingérées par les ovins, Ann. Zootechn. 20 (1971) 119-134.

[10] Dhanoa M.S., On the analysis of dacron bag data for low degradability feeds, Grass and Forage Sci. 43 (1988) 441-444. 
[11] Dulphy J.P., Jouany J.P., Martin-Rosset W., Thériez M., Aptitudes comparées de différentes espèces d'herbivores domestiques à ingérer et digérer des fourrages distribués à l'auge, Ann. Zootech. 43 (1994) 11-32.

[12] Goering H.K., Van Soest P.J., Forage fiber analysis. Apparatus, reagent, procedures and some applications, Agricultural Research Service, Agriculture Handbook No. 379, Washington, DC, 1970.

[13] Hatfield R.D., Cell-wall polysaccharide interactions and degradability, in: Jung H.G., Buxton D.R., Hatfield R.D., Ralph J. (Eds.), Forage Cell-wall Structure and Digestibility, American Society of Agronomy, Madison, 1993, pp. 285-313.

[14] Herrero M., Jessop N.S., Fawcett R.H., Murray I., Dent J.B., Prediction of the in vitro gas production dynamics of kikuyu gras by near-infrred reflectance spectroscopy using spectrally structured populations, Anim. Feed Sci. Technol. 69 (1997) 291-287.

[15] Hoden A., Barrière Y., Gallais A., Huguet L., Journet M., Mourguet M., Le maïs brown-midrib plante entière. III Utilisation sous forme d'ensilage par des vaches laitières, Bull. Tech. CRZV Theix, Inra 60 (1985) $43-58$.

[16] Hunt C.W., Kezar W., Vinande R., Yield, chemical composition, and ruminal fermentability of corn whole plant, ear, and stover as affected by hybrid, J. Prod. Agric. 5 (2) (1992) 286-290.

[17] Jung H.J.G., Deetz D.A., Cell-wall lignification and degradability, in: Jung H.G., Buxton D.R., Hatfield R.D., Ralph J. (Eds.), Forage Cell-wall Structure and Digestibility, American Society of Agronomy, Madison, 1993, pp. 315-346.

[18] Jung H.G., Buxton D.R., Forage quality variation among maize inbreds, Relationships of cell-wall composition and in vitro degradability for stem internodes, J. Sci. Food Agric. 66 (1994) 313-322.

[19] Jung H.G., Mertens D.R., Buxton D.R., Forage quality variation among maize inbreds, In vitro fiber digestion kinetics and prediction with NIRS, Crop Sci. 38 (1998) 205-210.

[20] Kamel H.E.M., Sekine J., Suga T., Morita Z., The effect of frozen-rethawing technique on detaching firmly associated bacteria from in situ hay residues, Can J. Anim. Sci. 75 (1995) 481-483.

[21] Klop A., de Visser H., Afbraak van snijmaissilage, maiskolvensilage en corn cob mix in de pens van melkkoeien, Rapport IVVO-DLO no. 262, ID-DLO Lelystad, the Netherlands, 1994, 37 p.

[22] Lam T.B.T., Iiyama K., Store B.A., Cinnamic acid bridges between cell wall polymers in wheat and phalaris internodes, Phytochemistry 31 (1992) 1179-1183.
[23] Lila M., Influence des modalités de séchage sur la mesure de la teneur des fourrages en éléments azotés et glucidiques. Conséquences lors des récoltes des essais en champs, Ann. Amélior. Plantes 27 (1977) 465-475.

[24] Lopez S., France J., Dhanoa M.S., A correction for particulate matter loss when applying the polyesterbag method, Br. J. Nutr. 71 (1994) 135-137.

[25] Mertens D.R., Kinetics of cell wall digestion and passge in ruminants, in: Jung H.G., Buxton D.R., Hatfield R.D., Ralph J. (Eds.), Forage Cell-wall Structure and Digestibility, American Society of Agronomy, Madison, 1993, pp. 535-545.

[26] Michalet-Doreau B., Verité R., Chapoutot P., Méthodologie de mesure de la dégradabilité in sacco de l'azote des aliments dans le rumen, Bull. Tech. CRZV Theix Inra 69 (1987) 5-7.

[27] Minson D.J., Wilson J.R., Prediction of intake as an element of forage quality, in: Fahey G.C. (Ed.), Forage Quality, Evaluation and Utilisation, American Society of Agronomy, Inc., Crop Science Society of America, Inc, Soil Science Society of America, Inc, Madison, Wisconsin, 1994, pp 533-563.

[28] Moran J.B., Lemerle C., Trigg T.E., The intake and digestion of maize silage-based by dairy cows and sheep, Anim. Feed Sci. Technol. 20 (1988) 239-312.

[29] Orskov E.R., McDonald I., The estimation of extent of protein degradability in the rumen from incubation measurements weighted according to rate of passage, J. Agric. Sci. Camb. 92 (1979) 499-504.

[30] Tamminga S., Van Vuuren A.M., Van der Koelen C.J., Ketelaar R.S., Van der Togt P.L., Ruminal behaviour of structural carbohydrates, non structural carbohydrates and crude protein from concentrates ingredients in dairy cows, Neth. J. Agric. Sci. 38 (1990) 513-536.

[31] Travis A.J., Murison S.D., Hirst D.J., Walker K.C., Chesson A., Comparison of the anatomy and degradability of straw from varieties of wheat and barley that differ in susceptibility to lodging, J. Agric. Sci. 127 (1996) 1-10.

[32] Tovar-Gomez M.R., Emile J.C., MichaletDoreau B., Barrière Y., In situ degradation kinetics of maize hybrids stalks, Anim. Feed Sci. Technol. 68 (1997) 77-88.

[33] Venables W.N., Ripley B.D., Modern Applied Statistics with Splus, Springer-Verlag, 1994, 462 p.

[34] Wilman D., Foulkes G.R., Givens D.I., The rate and extent of cell-wall degradation in vitro for 40 silages varying in composition and digestibility, Anim. Feed Sci. Technol. 63 (1996) 111-122. 